\title{
Successful Post-disaster Recovery Requires Adequate Pre-disaster Preparedness: The Case of Gulf Countries
}

\author{
Yassar Alamri, MBChB
}

W e read with great interest the findings and suggested conclusions by Ryan et al in their article, "Defining, Describing, and Categorizing Public Health Infrastructure Priorities for Tropical Cyclone, Flood, Storm, Tornado, and Tsunami-Related Disasters," published in the journal in August 2016. ${ }^{1}$ Such forward thinking with proper pre-disaster preparedness plans and post-disaster recovery plans is unfortunately lacking in some parts of the world. Countries of the Gulf Cooperation Council (GCC) often make the headlines for humanmade disasters such as conflicts and terrorist acts. Natural disasters, on the other hand, have long been regarded as rare events in this part of the world; preparedness for such disasters has therefore been considered a luxury and not a priority. ${ }^{2}$ However, the change in global climate and increased humaninduced hazards such as poor city designs and increased industrial hazards in the region have led to substantial vulnerability to natural disasters.

In 2007, Cyclone Gonu struck the coastline of Oman causing extensive damage to the infrastructure in the capital city and its surroundings. The cyclone claimed the life of 49 people and affected more than 20,000 others with an estimated total cost of US $\$ 4$ billion. It remains the worst disaster in Oman in decades. ${ }^{3}$ Similarly, in 2009, the city of Jeddah in Saudi Arabia was flooded. The floods killed 83 people and affected the entire city's roads, power, and water supplies. It is considered the worst disaster in Saudi Arabia in over 35 years. ${ }^{4}$

These 2 disasters have awakened policy-makers in the region to the importance of multidisciplinary and proactive disaster preparedness strategies. They have exposed some weak links in the chain of disaster preparedness in the region, which should be the target for improvement and policy changes. ${ }^{3,4}$ The ramifications of these disasters (and the lack of adequate preparedness) on the rate of recovery remain to date.
A focused and proactive approach, based upon prior experience with these events and modeled according to the Sendai Framework, ${ }^{5}$ ought to take priority in future strategic plans in the GCC (eg, Saudi Arabia's Vision $2030^{6}$ ) in order to efficiently minimize the impact of future disasters. The GCC is in a unique position to integrate resources and assimilate experiences gained through regional disasters (both humanmade and natural). Proper contingency plans and preparedness policies-if adopted - will enhance the readiness of populations in the region to respond effectively to such disastrous events.

\section{About the Author}

Canterbury District Health Board and New Zealand Brain Research Institute, Christchurch, New Zealand.

Correspondence and reprint requests to Yassar Alamri, MBChB, New Zealand Brain Research Institute, 66 Stewart Street, Central City 8011, Christchurch, New Zealand (e-mail: yassar.alamri@nzbri.org).

Published online: November 10, 2016.

\section{REFERENCES}

1. Ryan BJ, Franklin RC, Burkle FM, et al. Defining, describing, and categorizing public health infrastructure priorities for tropical cyclone, flood, storm, tornado, and tsunami-related disasters. Disaster Med Public Health Prep. 2016;10(4):598-610. http://dx.doi.org/10.1017/dmp.2016.3.

2. Al-Madhari A, Elberier M. Trends and fatality of natural disasters in the Arab World. Disaster Prev Manag. 1996;5(2): 27-35. http://dx.doi.org/10.1108/09653569610112899.

3. Al-Shaqsi S. Care or cry: three years from Cyclone Gonu. What have we learnt? Oman Med J. 2010;25(3):162-167. http://dx.doi.org/10.5001/omj.2010.50.

4. Alamri YA. Rains and floods in Saudi Arabia. Crying of the sky or of the people? Saudi Med J. 2011;32(3):311-313.

5. United Nations. Sendai Framework for Disaster Risk Reduction: 2015 - 2030. http://www.preventionweb.net/files/ 43291_sendaiframeworkfordrren.pdf. Accessed October 8, 2016.

6. Government of Saudi Arabia. Kingdom of Saudi Arabia: Vision 2030. http://vision2030.gov.sa/en. Accessed July 23, 2016. 